\title{
Recent Reports of Magneto-Mechano-Electric Conversion Composites
}

\author{
Geon-Tae Hwang ${ }^{1 \dagger}$, Jungho Ryu ${ }^{2}$, Woon-Ha Yoon ${ }^{3}$
}

${ }^{1}$ Department of Materials Science and Engineering, Pukyong National University, Busan 48513, Korea. ${ }^{2}$ School of Materials Science \& Engineering, Yeungnam University, Gyeongsan, Gyeongbuk 38541, Korea ${ }^{3}$ Korea Institute of Materials Science (KIMS), Changwon, Gyeongnam, 51508, Korea

\section{자기-기계-전기변환 복합체의 최신 연구동향}

\author{
황건태 ${ }^{\dagger}$, 류정호 $^{2}$, 윤운하 ${ }^{3}$ \\ 1부경대학교 재료공학과 \\ 2영남대학교 신소재공학부 \\ 3한국재료연구원 기능세라믹연구실
}

(Received August 8, 2021; Revised August 20, 2021; Accepted August 23, 2021)

\begin{abstract}
s
Magneto-mechano-electric (MME) conversion composites composed of distinctive magnetostrictive and piezoelectric materials derive interfacial coupling of magnetoelectric conversion between magnetic and electric properties, thus enabling energy harvesting and magnetic sensing. To demonstrate highperformance MME composites and their applications, various research teams have studied tailoring device structures, enhancing material properties, and developing MME application system. This article reviews the recent research progress of MME composites for energy harvesting and magnetic sensing.
\end{abstract}

Keywords: Magneto-mechano-electric, magnetic field, energy harvesting, magnetic sensing

\section{1. 서론}

다강체는(multiferroic materials)는 그림 1과 같이 강유전성(ferroelectric), 강탄성(ferroelastic), 강자성 (ferromagnetic), 반강자성(antiferromagnetic) 중 2
개 이상의 강성이 동시에 나타나는 소재를 의미한다. ${ }^{1)}$ 다강체에 대한 탐구는 1894년 프랑스의 유명한 과학자 Pierre Curie가 전기적 특성과 자기적 특성은 서로 결합 이 가능하다는 이론을 제시한 이래로 약 130 년 정도 연 구가 진행되었다. 다양한 다강체 특성 중 특히 연구가

†Corresponding Author: gthwang@pknu.ac.kr 


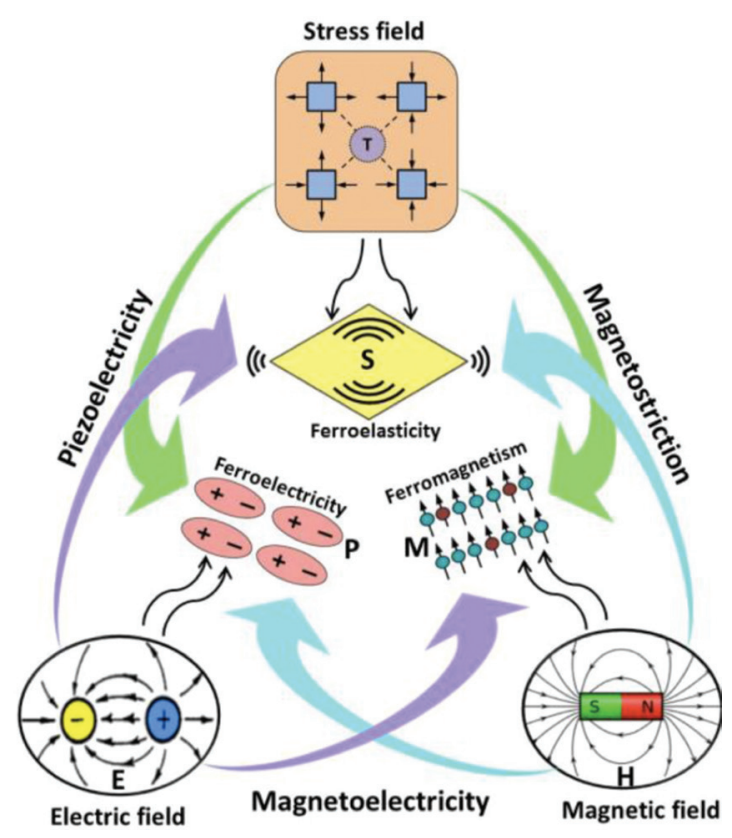

Fig. 1. Illustration of magnetic-elastic-electric couplings in multiferroic materials. Adapted from Palneedi et al. Actuators 2016:5:9 with permission of MDPI [1].

많이 진행된 분야는 자기-전기결합(magnetoelectric coupling)효과로, 이는 어떠한 재료가 자기장과 전기 장에 반응하는 특성을 동시에 가지고 있을 때, 자기장 에 노출되면 재료에 전기장이 형성되지만, 전기장에 노 출되면 반대로 재료에 자기장이 형성되는 특성을 보여 준다. ${ }^{2}$ 1960년대에 소련에서 최초로 발견된 자기-전 기결합 효과를 발생하는 물질은 산화크롬 $\left(\mathrm{Cr}_{2} \mathrm{O}_{3}\right)$ 기반 의 단결정인데, 이후 다양한 단일상 기반의 자기-전기 결합 재료들이 발견되었다. 하지만 이러한 단일상 재 료들의 강자성과 강유전성이 동시에 발현하기 위해서 는 큐리(Curie)온도 이하의 극저온 냉각이 필요하고 그 특성도 매우 미약하였기에, 상온에서 응용이 불가능 한 단점이 있었다. 이후 1970 년대에는 자기장에 반응 하는 자성특성의 물질과 전기장에 반응하는 강유전특 성의 물질을 복합화하여 자기-전기변환 특성을 구현하 였다. 처음에는 자성체인 페라이트(ferrite)와 강유전 체인 $\mathrm{BaTiO}_{3}$ 를 복합체로 제작하였으며, 1990 년대 말 까지 다양한 복합재료를 이용해 자기-전기변환 특성 을 구현하였다. 이렇듯 수십년에 걸쳐 다양한 시도를 통

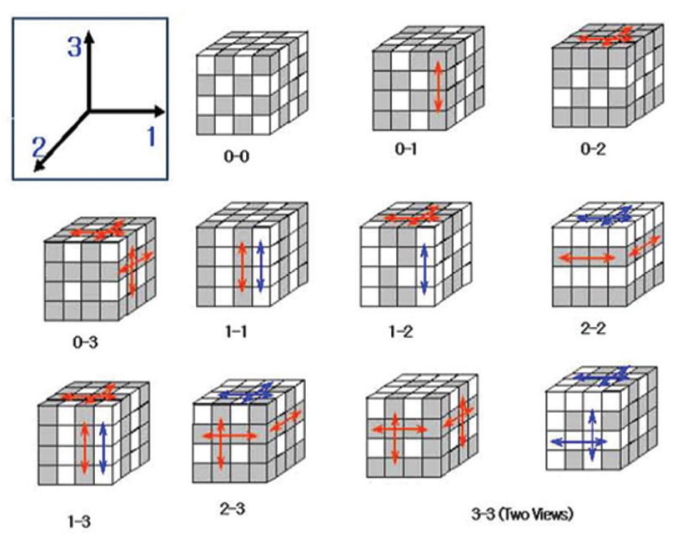

Fig. 2. Various connection structures of composites.

해 자기-전기변환 특성을 향상하는 노력을 시도 하였 지만 의미 있는 특성이 나오지 않아 실제 응용은 여전 히 어려운 상황이었다. 2000년대에는 자기-전기변환 복합체 분야에서 새로운 시도들이 보고 되었는데, 대표 적인 것이 그림 2 와 같은 다양한 복합체 구조 중에 자 왜재료와 압전재료를 층상형태의 복합체(1-1 또는 2-2 결합구조)로 제작하는 것이다. ${ }^{3)}$ 층상형태의 자기-전 기 복합체는 우수한 특성을 가지고 있는 자왜재료와 압 전재료를 각각 이용할 수 있기 때문에 기존까지 개발 된 자기-전기 복합체와 비교해 월등히 우수한 변환특 성을 보여주었다. ${ }^{4)}$ 이후로 자기-전기 층상형 복합체에 관한 연구가 전세계적으로 많이 진행 되었는데, 대표적 으로 미국의 경우 Office of Naval Research(ONR), National Science Foundation(NSF), Army Research Lab(ARL), Defense Advanced Research Projects Agency(DARPA) 등에서 폭넓은 관심을 가지고 연구개 발 투자와 소재개발, 시스템 응용개발 연구를 수행하고 있는 것으로 파악된다. 현재에는 층상형 자기-전기 복 합체를 이용한 상온에서의 의미 있는 연구결과 들이 많 이 보고되어 있는데, 본 리뷰에서는 층상형 자기-전기 변환 복합체에 대해 소개하고 최신 연구동향에 대해 다 루고자 한다. 
(a) 자기-전기변환 복합체
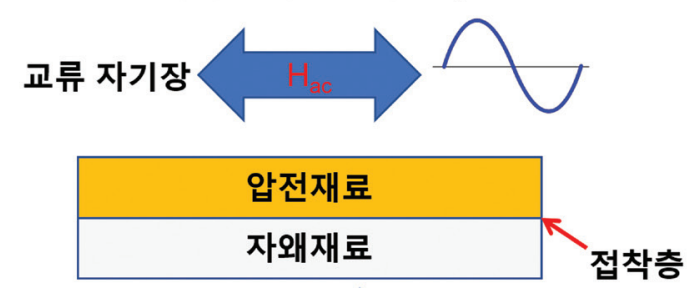

직류 자기장 (b)

\section{자기-전기변환 계수 ( $\left.\alpha_{M E}, V / c m \cdot O e\right)$}

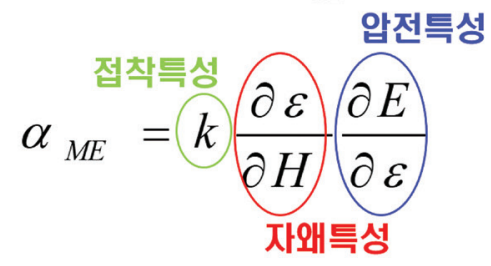

Fig. 3. (a) working principle of MME composite, (b) equation of magnetoelectric coupling coefficient

\section{2. 자기-전기변환 복합체}

자왜재료 및 압전재료의 층상형 복합체에서 자기-전 기변환 특성이 구현되는 원리는 그림 $3(\mathrm{a})$ 와 같다. 층 상형 자기-전기 복합체는 자왜재료와 압전재료가 계 면 적찹층에 의해 물리적으로 부착되어 있는 형태인데, 외부에서 자기장이 발생하면 자왜재료는 자화과정에 서 재료의 형태가 변하는 자왜효과(magnetostrictive effect)에 의해 기계적인 변형을 일으키고, 이는 물리적 으로 결합되어 있는 압전재료에 응력으로 전달되어 유 전분극 특성이 변화하는 압전효과(piezoelectric effect) 를 유발하며 전압 등의 전기적인 신호를 발생할 수 있 다. 이는 자기에너지-기계에너지 변환 및 기계에너 지-전기에너지 변환의 2 단계의 변환을 포함하고 있 기 때문에 이를 통합하여 자기-기계-전기(magnetomechano-electric, MME)변환으로도 부른다. 자기전기변환 특성을 수치화 시켜 나타낸 것이 자기-전 기변환 계수 $\alpha_{\mathrm{ME}}$ 인데, 이는 그림 3(b)와 같이 자왜상 수(magnetostrictive coefficient; d $\mathrm{d} / \mathrm{dH}$ ), 압전상수 (piezoelectric coefficient; $\mathrm{dE} / \mathrm{d} \varepsilon$ ), 계면접착층의 응력 전달 특성의 항목으로 이루어져 있으며, 주어진 단위 자 기장 $(1 \mathrm{Oe})$ 에 의해 $1 \mathrm{~cm}$ 두께의 압전체에서 생성하는 전 압의 크기 $(\mathrm{V} / \mathrm{cm} \cdot \mathrm{Oe})$ 로 정의된다. ${ }^{5}$ 층상형 복합체에서 의 자기-전기변환 특성은 자왜효과와 압전효과가 결합 되어 나타나기 때문에 우수한 특성의 자왜재료 및 압전 재료를 사용하는 것이 유리하고, 두 재료간 계면결합특
성 $(\mathrm{k})$ 이 우수해 자왜재료에서 발생하는 변형(응력)은 압 전재료로 잘 전달되어야 한다. 일반적으로 자왜재료와 압전재료를 물리적으로 결합하기 위해서 고분자 접착물 질이 사용된다. 이러한 고분자 물질은 무기계열의 자왜/ 압전재료와 비교했을 때 Young's modulus가 무척 낮은 데, 이러한 특성으로 말미암아 자왜재료에서 발생한 응 력은 압전재료로 온전히 전달되지 않고 고분자 계면접 착물질에서 흡수하는 결과를 가져온다. 이때문에 자기전기 복합체에서 고분자 접착층에 의한 응력 흡수를 최 소화하는 것이 중요한데, 가능하면 Young's modulus 가 큰 고분자 물질을 이용하거나 접착층의 두께를 최소 화하는 것이 계면결합특성을 향상하는데 유리하다. 이 렇듯 자기-전기 복합체의 성능을 결정짓는 다양한 요소 로 인해 층상형의 자기-전기 복합체의 특성을 향상하기 위해 자왜재료, 압전재료, 계면층 최적화 등의 연구가 이루어졌다.

현재까지 자기-전기 복합체를 제작하기 위해 다양한 자왜재료 및 압전재료가 사용되었으며, 현재까지 관련 연구에 사용된 대표적인 물질 및 특성들은 아래의 표1에 정리가 되어있다. 자왜재료로는 $\mathrm{FeBSi}$ 합금(Metglas), $\mathrm{GaFe}$ 합금(Galfenol), $\mathrm{Tb}_{\mathrm{x}} \mathrm{Dy}_{1-\mathrm{x}}-\mathrm{Fe}_{2}$ (Terfenol-D) 등 이 있으며, 압전물질로는 세라믹 $\mathrm{Pb}\left(\mathrm{Zr}_{\mathrm{x}} \mathrm{Ti}_{1-\mathrm{x}}\right) \mathrm{O}_{3}(\mathrm{PZT})$, 단결정 $\mathrm{Pb}\left(\mathrm{Mg}_{1 / 3} \mathrm{Nb}_{2 / 3}\right) \mathrm{O}_{3}-\mathrm{PbTiO}_{3}(\mathrm{PMN}-\mathrm{PT})$ 및 $\mathrm{Pb}\left(\mathrm{Mg}_{1 / 3} \mathrm{Nb}_{2 / 3}\right) \mathrm{O}_{3}-\mathrm{Pb}(\mathrm{Zr}, \mathrm{Ti}) \mathrm{O}_{3}$ (PMN-PZT), 폴리머 계열의 Polyvinylidene fluoride (PVDF) 등이 있다. 
Table 1. 자기-전기 복합체 제작에 사용된 다양한 자왜재료 및 압전재료의 물성

\begin{tabular}{c|c|c|c|c|c|c}
\hline 물질명 & 영률 $(\mathrm{GPa})$ & $\mu \mathrm{r}$ & $\mathrm{d}_{33, \mathrm{~m}}(\mathrm{~nm} / \mathrm{A})$ & $\mathrm{G}_{33, \mathrm{p}}(\mathrm{mVm} / \mathrm{N})$ & $\mathrm{k}_{33, \mathrm{p}}$ & $\varepsilon^{\mathrm{T}}$ \\
\hline Metglas & 100 & 45,000 & 50.3 & & & \\
\hline Galfenol & 86 & 350 & 40 & & & \\
\hline Terfenol-D & 35 & 12 & 20 & & & \\
\hline PZT(5A) & 66 & & & 26.1 & 0.73 & 1,750 \\
\hline PVDF & 2.2 & & & 32.0 & 0.27 & 8.4 \\
\hline PMN-PT & 112 & & & 53.1 & 0.89 & 4,000 \\
\hline PMN-PZT & 66 & & & 33.3 & 0.92 & 4,500 \\
\hline
\end{tabular}

\section{3. 자기-전기변환 층상복합체의 응용범위}

자기-전기변환 층상 복합체는 주변에서 발생하는 자 기장을 이용해 전기적 신호를 생성할 수 있기 때문에 응 용할 수 있는 대표적 분야로는 그림 $4(\mathrm{a}),(\mathrm{b})$ 와 같이 버려지는 자기장을 활용해 유용한 에너지를 생성하는 에너지 하베스팅(energy harvesting) 및 다양한 목적으 로 미세한 자기장을 감지하는 자기장 센싱 분야이다.

(a)

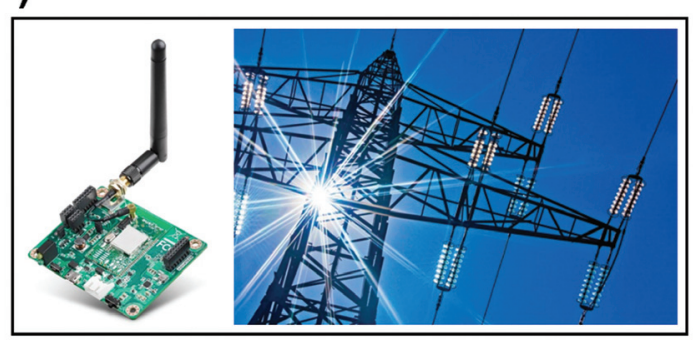

(b)

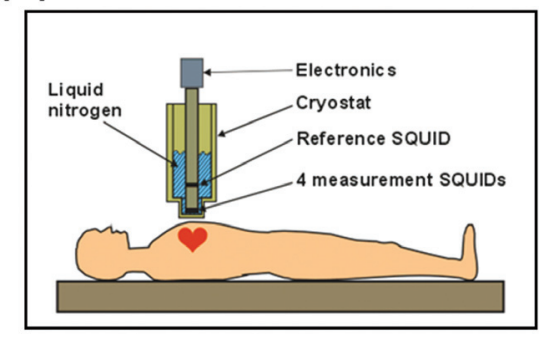

Fig. 4. (a) Energy harvesting near electric cables, (b) detection of biomagnetism from human healthcare.

\section{1 에너지 하베스팅 분야에서의 응용}

사물인터넷(Internet of Thing, IoT)기술은 4차 산업 혁명에서의 핵심요소 중 하나인데, 각종 사물에 무선으 로 동작하는 센서를 부착하여 다양한 정보를 모니터링 하거나 기기 등을 제어하는 역할을 하고 있다. 사물인터 넷 기기의 전원 공급을 위해 많은 경우 배터리가 사용되 지만 제한적인 용량 때문에 주기적인 교체가 필요하다. 하지만 매우 많은 수의 센서들이 존재하고 사람이 접근 하기 어려운 공간에 장착되는 경우도 많아 향후 유지/보 수에 큰 비용 및 인력이 소모될 수 있다. 이러한 문제점 을 해결하기 위해 태양광 발전 등의 다양한 에너지 하베 스팅 기술들이 현재 연구되고 있으며, 자연환경 및 우리 주변에서 버려지는 에너지원을 이용하여 전기 에너지를 생산하고 배터리를 충전하거나 대체하려고 한다. 특히 자기-전기 복합체는 버려지는 교류 자기장 분위기에서 전기 에너지 생성이 가능한 장점이 있다. 전선은 발전소 에서 생성된 전기에너지를 적재적소에 $60 \mathrm{~Hz}$ 의 교류형 태로 전송하기위해 매우 다양한 곳에 설치되어 있는데, 암페어의 법칙(Ampere's law)에 의해 전선주변에는 필 연적으로 미세한 교류 자기장이 발생한다. 교류 자기장 이 발생하는 전선주변에 자기-전기변환 복합체를 설치 하면 버려지는 교류 자기장으로 쓸모 있는 전기에너지 수확이 가능하다. 특히 자기-전기변환은 전력의 송배전 분야에서 널리 쓰일 수 있는데, 송배전 관련 선로는 전 국토에 걸쳐 고르게 분포되어 있고 비교적 큰 교류 자기 장을 발생시켜 자기-전기 복합체를 이용하면 충분한 에 너지 발전이 가능하다. ${ }^{6)}$ 만약 송배전 선로에 문제가 생 


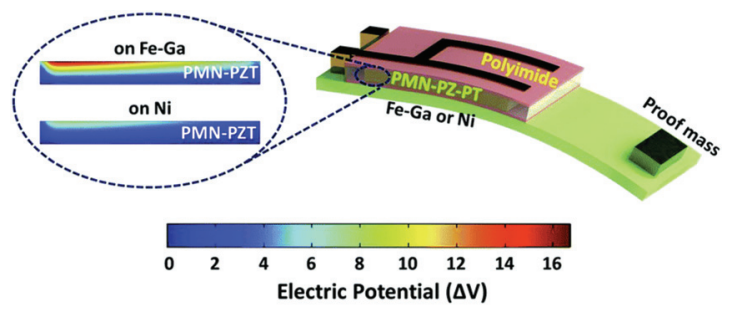

Fig. 5. Cantilever type MME generator with magnet proof mass. Adapted from Annapureddy et al. Energy Environ. Sci. 2018;11:818 with permission of Royal Society of Chemistry [6].

기면 정전이나 대형 화재 등을 유발하여 사회/경제적으 로 큰 손실을 가져올 수 있기 때문에 IoT 센서 등을 이 용한 송배전 선로 건전성의 실시간 감지 필요성이 높아 지고 있다. 최근에 개발되고 있는 자기-전기 층상 복합 체 기반 에너지 발전소자의 경우 자왜재료 및 압전재료 외에도 그림 5 에서 보이는 것처럼 자기장에서 자기력을 발생하여 압전체의 변형을 더욱더 크게 만드는 자석 질 량체를 도입하였는데, 이러한 구조로 말미암아 수 $\mathrm{mW}$ 의 전력을 발생시킬 수 있어 다양한 저전력 IoT 센서의 구동이 가능하다. 향후 지속적인 연구를 통해 자기-전 기 복합체 기반 에너지 발전소자에서 발생하는 전력의 크기를 $100 \mathrm{~mW}$ 수준으로 향상할 수 있으면 다기능 사 물인터넷 센서를 실시간으로 구동하는 등 보다 광범위 한 분야에서 효과적으로 시설물의 진단 및 감시를 제공 할 것이다.

\section{2 미세 자기장 감지 분야에서의 응용}

미세 자기장 감지는 바다속의 잠수함 등을 감지하는 군사분야 및 생체의 자기장을 감지하는 의료분야에 대 표적으로 쓰이고 있다. 특히 살아있는 생명체는 생명유 지를 위해 세포막을 통해 다양한 이온들을 끊임없이 교 환하는데, 이때 암페어의 법칙에 의해 매우 미세한 자 기장을 만들어 낸다. 이러한 생체에서 발생하는 미세 자 기장을 측정하면 질병의 진단 및 예측이 가능한데, 대 표적으로 심장 및 뇌와 관련된 질병 및 이상징후를 파악 할 수 있고 관련 연구분야에도 응용할 수 있다. 인체에 서의 미세자기장은 부위에 따라 뇌신경세포, 심장근육

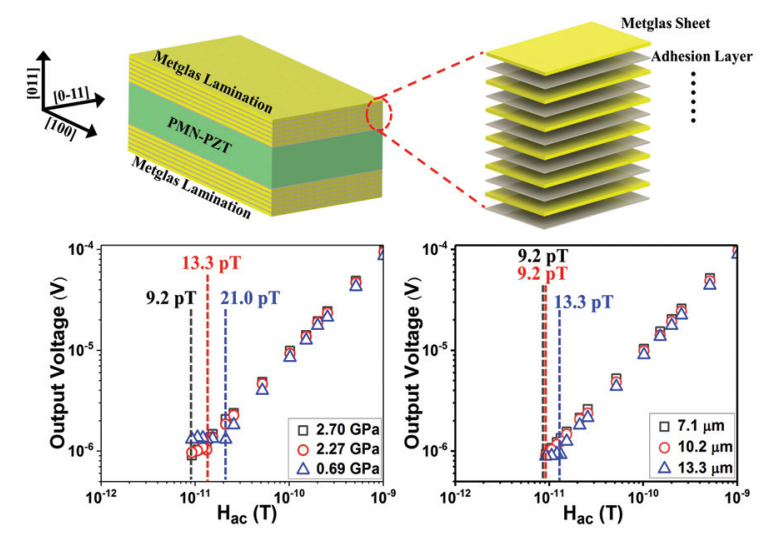

Fig. 6. Sensing of tiny magnetic field by MME composite structure. Adapted from Hwang et al. ACS Appl. Mater. Interfaces. 2018;10:38 with permission of American Chemical Society [7].

세포, 척수신경세포 등에서 발생하며, 세포 집단의 부 위별 부피에 의해 발생하는 자기장의 크기가 달라지는 데 척수에서는 약 $10 \mathrm{fT}$, 뇌에서는 약 $100 \mathrm{fT}$, 심장에 서는 약 $10 \mathrm{pT}$ 수준의 초미세 자기장이 발생한다. 이는 지구에서 발생되는 지구 자기장의 크기인 $50 \mu \mathrm{T}$ 와 비 교했을 때 매우 작은 수치임을 알 수 있다. 지난 수십 년간 미세 자기장을 감지하기 위해 다양한 방법들이 사 용되었으며 기술적으로도 많은 발전이 이루어졌다. 미 세 자기장의 검출방법 중 현존하는 최고의 감도를 나타 내는 방법은 초전도 양자간섭장치(superconducting quantum interference device; SQUID)인데, 이는 조 셉슨(Josephson)효과를 기반으로 $0.1 \mathrm{fT}$ 수준의 초미세 자기장도 감지 가능하다. 하지만 SQUID의 경우 액체 헬륨을 이용한 극저온의 냉각이 필요하여 전체 시스템 의 부피가 큰 편이고, 초기 구입 및 유지하기 위해 많은 비용이 들어가는 단점이 있다. 이러한 SQUID의 단점에 서 기인하여 자기-전기변환 층상 복합체를 이용한 미세 자기장 감지에 관한 연구가 진행되고 있는데, 자기-전 기 복합체는 SQUID의 단점을 가지고 있지 않으면서 고 민감도, 작은 부피, 저비용 구현의 장점을 가지고 있다. 현재까지 개발된 자기-전기 복합체 기반의 자기장 센서 는 다양한 연구적 시도를 통해 성능을 점차 개선시켜 나 가고 있고(그림 6), 현재에는 $1 \mathrm{pT}$ 이하의 매우 미세한 
자기장을 감지할 수 있기 때문에 미래에는 생체신호 및 다양한 분야에서 미세 자기장을 감지하는 소자로써 활 용이 가능 할 것이다. ${ }^{7)}$

\section{4. 자기-전기변환 층상구조 복합체의 쵝신 연구동향}

\section{1 세계 최고의 자기-전기변환계수 획득}

2020년 중국 북경대 연구팀은 자왜-압전 층상복합 체에서 세계 최고의 자기-전기 변환계수인 $12,500 \mathrm{~V} /$ $\mathrm{cm} \cdot \mathrm{Oe}$ 달성에 성공하였다. ${ }^{8)}$ Metglas라고 불리는 (a)

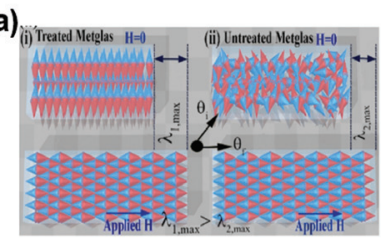

(c)

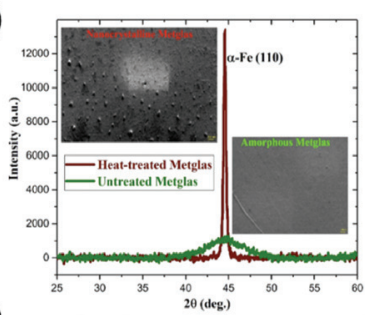

(b)

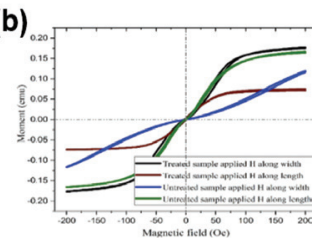

(d)

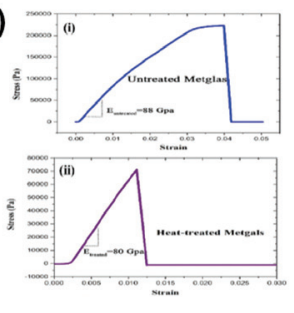

(e)

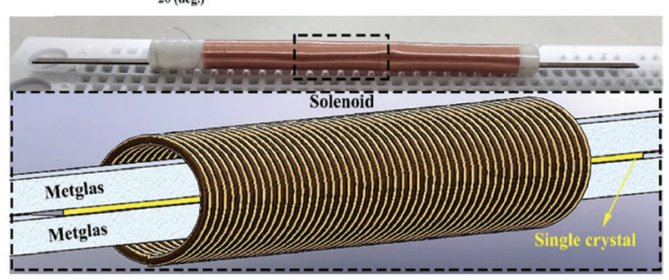

(f)

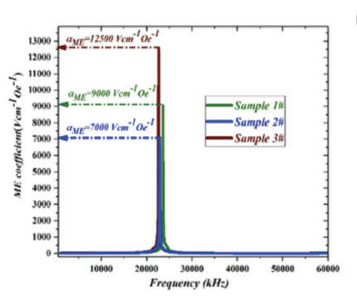

(g)

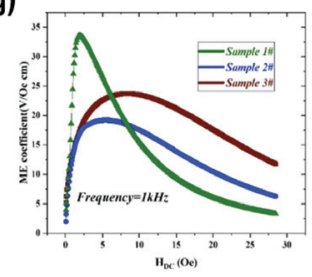

Fig. 7. (a) Illustration of micro magnetic domain distributions before and after laser heat treatment, (b) $\mathrm{M}-\mathrm{H}$ curve for treated and untreated samples, (c) XRD pattern and SEM image, (d) mechanical properties of amorphous and nanocrystalline MME samples. Adapted from PourhosseiniAsl et al. Nano Energy. 2020;70:104506 with permission of Elsevier [8].
$\mathrm{FeBSi}$ 합금 호일은 우수한 자왜재료로 층상형 자기전기 복합체 제조에 널리 쓰이고 있다. 비정질 상태의 Metglas 호일은 상태 투자율이 수만에 달하는 매우 높 은 값을 가지고 있어 자기장 집중효과를 통해 내부에 높 은 자속밀도를 유발하며 우수한 자기-전기변환 특성 을 보여줄 수 있다. 연구팀은 Metglas에 레이저를 이용 해 표면 부분만 열처리를 진행하여 표면 결정화를 진행 하였다. 비정질의 Metglas 표면을 레이저를 이용해 열 처리하면 그림 7(a)와 같이 Metglas 리본의 폭 방향으 로 자기 도메인이 정렬된다는 가정을 세웠다. 비정질 Metglas의 경우 폭 방향으로 비교적 무작위의 자기 도 메인 방향을 가지고 있기 때문에, 리본의 폭 방향으로 도메인을 정렬하면 외부에서 자기장이 주어졌을 때 더 욱더 큰 자왜변형을 유발할 수 있다. 레이저 열처리에 따른 Metglas 리본에서의 자기 도메인의 정렬 방향을 확인하기 위해 $\mathrm{M}-\mathrm{H}$ 커브를 측정해 보았는데, 비정질 Metglas를 레이저 열처리하였을 때 폭 방향으로의 자 화가 더 잘 일어나는 것을 확인하였다. 이는 레이저 열 처리에 의해 표면 결정화가 일어나면서 자기 도메인의 방향이 폭 방향으로 정렬되었음을 의미한다. Metglas 의 레이저 열처리 전/후 결정화 정도를 그림 7(c)와 같이 $\mathrm{X}$-선 회절(XRD)분석을 통해 확인해 보았는데, 열처리 후에 약 $45^{\circ}$ 전후로 큰 피크가 발생하였음을 알 수 있고 이는 결정화된 $\alpha-\mathrm{Fe}$ 와 관련된 것이다. 또한 레이저 열 처리를 통해 Metglas의 기계적 특성도 향상시킬 수 있 었는데, 그림 7(d)와 같이 응력-변형률을 측정해 보았 을 때, 레이저 열처리 후 Young's modulus가 증가하고 선형적인 탄성 변형을 나타내어 자기-전기 복합체의 동 작에서 기계적인 에너지 손실이 감소됨을 알 수 있었다. 본 연구에서 압전물질은 단결정의 $\mathrm{Pb}\left(\mathrm{Mg}_{1 / 3} \mathrm{Nb}_{2 / 3}\right) \mathrm{O}_{3}-$ $\mathrm{Pb}(\mathrm{Zr}, \mathrm{Ti}) \mathrm{O}_{3}(\mathrm{PMN}-\mathrm{PZT})$ 를 이용하였는데, 경화제 첨가 를 통해 보다 경질의 특성을 가지는 단결정 $\mathrm{PMN}-\mathrm{PZT}$ 를 도입하였다. 이는 기존의 PMN-PZT 보다 압전특성 은 떨어지지만 기계적 품질계수가 월등히 증가하여 공 진 분위기에서 자기-전기 복합체를 동작할 때 기계적인 에너지 손실을 최소화 해 준다. 이렇게 제작된 자기-전 기 복합체를 그림 $7(\mathrm{e})$ 와 같이 솔레노이드 코일 내에서 


\section{특 집 ㅁㅃ 황건태, 류정호, 윤운하}

성능평가를 진행하였는데, 레이저 열처리된 Metglas 및 경화된 단결정 $\mathrm{PMN}-\mathrm{PZT}$ 를 이용한 경우(sample \#1)에 자기-전기 변환계수는 약 $125,000 \mathrm{~V} / \mathrm{cm} \cdot \mathrm{Oe}$ 을 달성 하였고, 레이저 열처리된 Metglas 및 도핑되지 않은 단 결정 PMN-PZT를 사용한 경우에는 $9,000 \mathrm{~V} / \mathrm{cm} \cdot \mathrm{Oe}$, 비정질 Metglas 및 경화된 단결정을 사용한 경우에 는 약 $7,000 \mathrm{~V} / \mathrm{cm} \cdot \mathrm{Oe}$ 을 달성하였다. 이를 통해 레이 저 열처리를 통한 Metglas의 결정화 및 경화된 단결정 $\mathrm{PMN}-\mathrm{PZT}$ 를 이용한 자기-전기변환 성능향상이 뚜렷 하게 이루어졌음을 확인하였다. 본 연구결과에서 제시 한 $125,000 \mathrm{~V} / \mathrm{cm} \cdot \mathrm{Oe}$ 의 자기-전기변환계수는 현존하 는 세계최고의 값으로, 이를 이용하면 향후 초미세 자기 장 감지용 센서 및 고성능의 $\mathrm{I}-\mathrm{V}$ 변환용 전자부품을 제 작할 수 있을 것이다.

\subsection{1 차원의 자기-전기 복합체 배열을 이용한 자기 스케치}

지난 수십년간 자기 물체 감지 및 이미징을 위해 여 러가지 원리를 이용한 시스템이 제작되었다. ${ }^{9}$ 대표적으 로 패러데이의(Faraday's) 유도 법칙을 이용한 탐지코 일, 두 개의 코일로 둘러싸인 강자성 물질로 구성된 플 럭스게이트(fluxgate) 센서, 앞서 언급한 SQUID 등이 이용되었는데, 이러한 방법 들은 커다란 부피, 높은 전 력 소모, 비싼 비용 등의 문제를 가지고 있다. 가격이 저 렴해 널리 사용되는 홀 효과(hall effect)기반의 자기장 센서의 경우 감지할 수 있는 최소 자기장의 크기가 100 $\mathrm{nT}$ 이기 때문에 작은 자기장 변화를 감지하기 어려운 단 점이 있다. 한편 자기-전기 복합체를 이용해 미세 자 기장을 감지하려는 연구결과가 다수 보고 되었으나 단 일 소자 기반의 매우 단순한 형태이고, 자기장의 크기 는 감지할 수 있지만 자성체의 위치 및 형상 등의 정보 는 얻기 어려웠다. 2019년 중국 북경대의 연구팀은 층 상형 자기-전기 복합체 배열을 이용해 움직이는 자성체 의 위치, 각도 방향, 길이비율을 감지하는 연구를 진행 하였다. ${ }^{10)}$ 연구팀은 자왜재료인 Metglas와 압전 단결정 $\mathrm{PMN}-\mathrm{PZT}$ 를 이용해 길쭉한(1차원) 형태의 자기-전기 층상형 복합체를 제작하였다. 이때 Metglas 호일을 5장
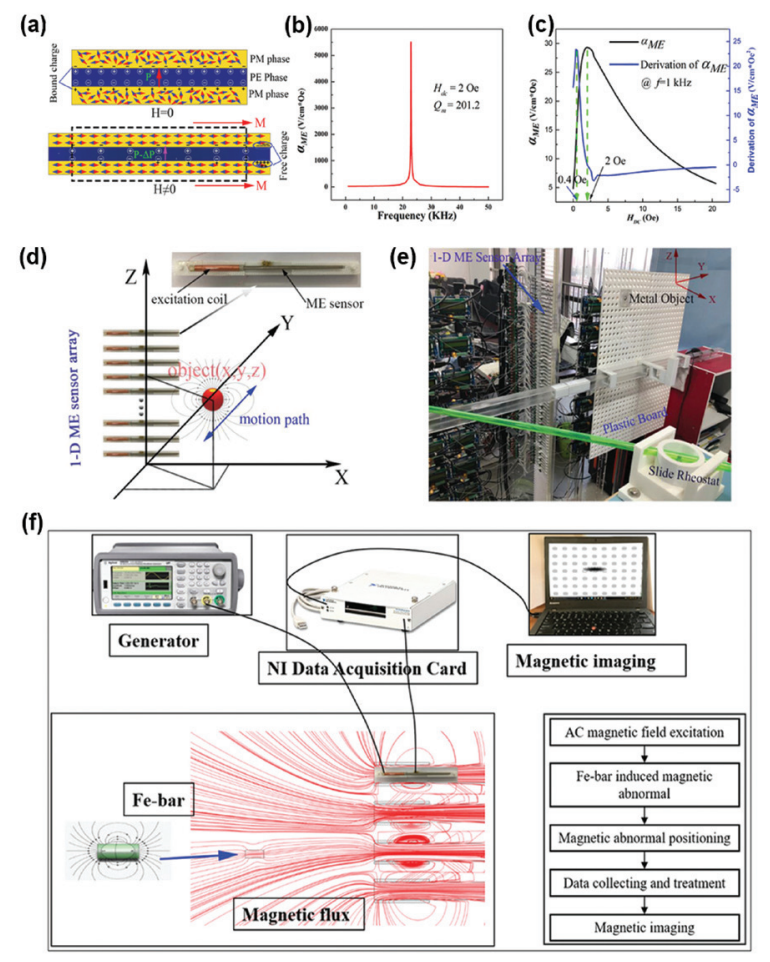

Fig. 8. (a) The schematic of magnetoelectric coupling effect, (b) the frequency and (c) DC magnetic field dependence of the MME coupling properties of 1-1 laminated composite, (d) schematic view of magnetic material detection using MME sensor array, (e) photo image of measurement setup, ( $f$ ) schematic view of MME-based magnetic detecting and positioning system. Adapted from Chu et al. Adv. Mater. Technol. 2019;4:1800484 with permission of Wiley [10].

겹쳐 다층구조를 형성하였으며 이것을 압전체 아래 위 에 부착하여 그림 8(a)와 같은 구조의 층상 복합체를 제 작하였다. 제작된 1 차원 형태 복합체의 자기-전기변환 계수를 공진 및 비공진 분위기에서 측정을 진행하였는 데, 그림 8(b), (c)처럼 공진 분위기에서는 약 $5,600 \mathrm{~V} /$ $\mathrm{cm} \cdot \mathrm{Oe}$, 비공진 분위기에서는 $28 \mathrm{~V} / \mathrm{cm} \cdot \mathrm{Oe}$ 를 달성하 였다. 그림 $8(\mathrm{~d}),(\mathrm{e})$ 는 자기 감지 및 스케치 시스템의 개 략도 및 실제 모습을 보여주는데, 센서 배열 구성을 위 해 총 56 개의 자기-전기 층상형 복합체가 수직한 방향 으로 $1.2 \mathrm{~cm}$ 의 간격을 두고 배열되었다. 각각의 자기전기 복합체 소자는 생성되는 전기적 신호를 개별적으 로 측정하고 분석할 수 있는 계측장비에 연결이 되어 2 
차원 공간에서의 자기 스케칭이 가능 하도록 구성이 되 었다. 자기 이미징 시스템은 그림 8(f)와 같은 방식으로 구동이 되는데, 먼저 자기-전기 복합체에 자기장을 인 가하기 위해 코일에 교류전류를 공급하면 자기-전기변 환 효과에 의해 복합체에서 전압이 생성된다. 만약 철과 같은 자성체가 자기-전기 복합체 배열주변을 통과하면 각각의 코일에서 발생된 자속의 변형이 발생하는데, 이 때문에 자기-전기 복합체에서 생성하는 전압 값의 변화 가 생긴다. 56 개의 자기-전기 복합체는 실시간으로 동 작이 되고 있으므로, 자성체가 특정 복합체 주변으로 지 나가게 되면 그 복합체에서 발생되는 전압 신호의 크기 는 다른 복합체와 비교했을 때 차이가 발생한다. 이러 한 신호의 변화 패턴을 분석함으로써 스케치하고자 하 는 자성체의 $\mathrm{y}$ 축에서의 위치 파악이 가능하다. 자성체가 $\mathrm{x}$ 축 방향으로 멀어지는 경우에는 코일에서 발생하는 자 속의 크기에 작은 영향을 주고, 자기-전기 복합체에서 신호에도 작은 변화를 유발할 것이다. 이러한 원리를 이 용해 본 연구에서는 $\mathrm{x}-\mathrm{y}$ 2차원 평면에서의 자성체의 형 태, 위치, 이동방향 등을 파악하는데 성공하였다. 이처 럼 자기-전기 복합체를 이용하면 매우 저렴한 비용으로 자기 스케치 시스템 구성이 가능하고 생체에도 안전하 게 적용할 수 있기 때문에 향후 다양한 분야에서의 응용 이 기대된다.

\section{3 자왜재료 층의 두께 조절을 통한 자기-전기 복합체 발전소자의 출력 향상}

층상형 자기-전기 복합체를 다용도로 사물인터넷에 적용하기 위해서는 $60 \mathrm{~Hz}$ 의 주파수, $10 \mathrm{Oe}$ 이하의 교류 자기장 분위기에서 충분한 에너지를 출력해야 한다. 이 를 위해 몇 년간 다양한 방법들이 시도되었는데, 2018 년 미국 펜실베니아 주립대학교 연구팀에서는 자왜재료 층의 두께 조절을 통해 자기-전기 층상복합체의 에너 지 출력을 극대화하였고 이를 이용해 사물인터넷 소자 를 구동 하였다. ${ }^{11)}$ 본 연구에서는 자왜재료로 Metglas, 압전재료로 세라믹의 $\mathrm{PbZr}_{\mathrm{x}} \mathrm{Ti}_{1-\mathrm{x}} \mathrm{O}_{3}(\mathrm{PZT})$ 를 이용하였다. 자왜재료인 Metglas는 그림 9(a)와 같이 다층구조로 되 어있고, 에너지 하베스팅시 캔틸레버(cantilever)의 역
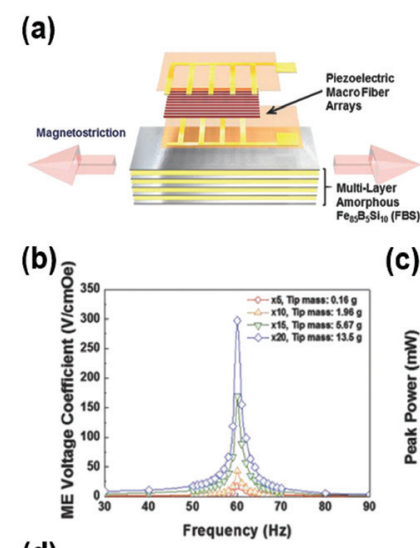

(c)
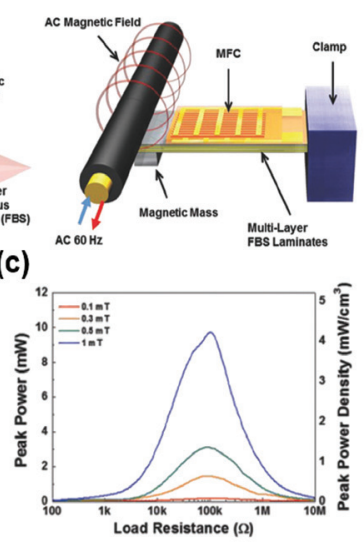

(d)

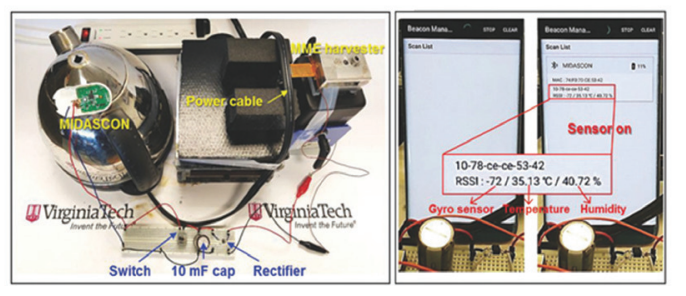

Fig. 9. (a) Schematic illustrations of MME composite and magnetic field energy harvesting using MME generator, (b) magnetoelectric voltage coefficient of the MME generators as function of magnetic field frequency, (c) output peak power of MME generator, (d) demonstration for self-powered wireless sensor system. Adapted from Kang et al. Adv. Energy Mater. 2018;8:1703313 with permission of Wiley [11].

할을 수행한다. 일반적으로 전력선은 $60 \mathrm{~Hz}$ 의 주파수를 가지는 교류 전력을 전송하는데, 효과적인 자기-전기 발전을 하기 위해서는 층상 복합체의 공진 주파수를 60 $\mathrm{Hz}$ 에 맞추어야 캔틸레버의 움직이는 진폭이 극대화되 어 높은 에너지 출력이 가능하다. 연구팀은 자왜 캔틸레 버로 이용되는 Metglas 호일의 층수를 조절하며 출력을 살펴보았는데, 5 층, 10 층, 15 층, 20 층의 Metglas 캔틸 레버를 이용해 자기-전기 복합체의 특성을 살펴보았다. 발전소자의 공진 주파수를 $60 \mathrm{~Hz}$ 에 맞추어야 하기 때문 에 자석 질량체는 $0.16 \mathrm{~g}, 1.96 \mathrm{~g}, 5.57 \mathrm{~g}, 13.5 \mathrm{~g}$ 을 각 각 이용하였는데, 자석 질량체가 무겁고 클수록 자기장 분위기에서 더욱더 큰 자기력이 발생하여 자왜 캔틸레 버를 크게 변형하는데 유리하다. 또한 Metglas의 두께 가 두꺼울수록 압전층에 가해지는 응력을 증가시켜 압 전층에서 큰 출력을 얻을 수 있다. 이러한 이유 때문에 


\section{특 집 ㅁㅃ 황건태, 류정호, 윤운하}

자왜층의 두께가 증가하고 자석 질량체의 무게가 증가 할수록 높은 출력발생이 가능하였는데, 20층의 Metglas 및 $13.5 \mathrm{~g}$ 의 자석 질량체를 사용한 경우 $300 \mathrm{~V} / \mathrm{cm} \cdot \mathrm{Oe}$ 의 자기-전기 변환계수를 달성하였다. 자기-전기 복합 체에 가해지는 교류 자기장의 크기를 바꾸어 가며 생성 되는 에너지 출력을 측정해 보았는데, $0.1 \mathrm{Oe}$ 일 때 0.18 $\mathrm{mW}$ 이던 순간출력은 $1 \mathrm{Oe}$ 에서 $9.7 \mathrm{~mW}$ 까지 증가하였 다. 자기장이 커질수록 자왜재료에서 발생하는 변형이 커지고 자석 질량체에서 발생하는 자기력 또한 커지므 로, 압전층에서 발생하는 전기 에너지의 크기가 비례해 서 증가함을 알 수 있다. 이후 전기 물 끓이기를 동작할 때 전선에서 발생하는 자기장을 이용해 자기-전기 복 합체를 구동해 보았는데 최대 $2.65 \mathrm{~mW}$ 의 순간출력이 발생되었다. 이때 발생한 전기 에너지는 교류 형태이므 로 사물인터넷 기기에 공급하기 위해서는 정류 및 전압 의 크기조절이 필요하다. 이를 위해 상용의 정류기와 10 $\mathrm{mF}$ 의 수퍼 커패시터(super capacitor)가 이용하였는 데, 그림 $9(\mathrm{~d})$ 와 같은 자가발전형 사물인터넷 구동 시스 템을 구성하였을 때 물 끓이기를 이용해 물을 한 번 끓 이게 되면 이동 방향, 온도, 습도를 측정하는 사물인터 넷 센서는 총 6 회의 센싱 및 무선전송을 실시하였다. 이 를 통해 가전제품에서 발생하는 작은 크기의 자기장으 로도 자기-전기 층상형 복합체는 에너지를 생성하고 유 비쿼터스(ubiquitous) 전원으로 사용될 수 있는 가능성 을 확인 하였다.

\section{4 자석 질량체의 분산을 통한 자기-전기 복합체의 전력 향상}

앞서 언급했듯이 자기-전기 층상형 복합체 발전소자 의 출력향상 및 공진주파수 조절을 위해서는 자석 질량 체가 캔틸레버 구조의 끝 부분에 고정된다. 2020년 미 국 펜실베니아 주립대학교 연구팀은 캔틸레버 구조체에 자석 질량체를 추가로 부착하여 자석 질량체를 분산시 켰고 이를 통해 자기-전기 에너지 발전특성을 향상하는 데 성공하였다. ${ }^{12)}$ 자기-전기 복합체 기반의 발전소자는 그림 10(a)와 같이 송전선 등에서 발생하는 교류 자기장 을 이용하여 전력선의 건전성 감시용 무선 센서의 전원
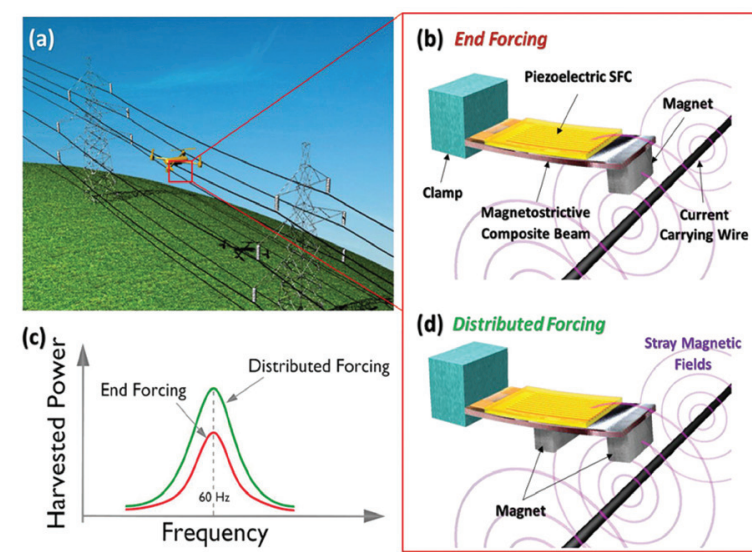

(e)
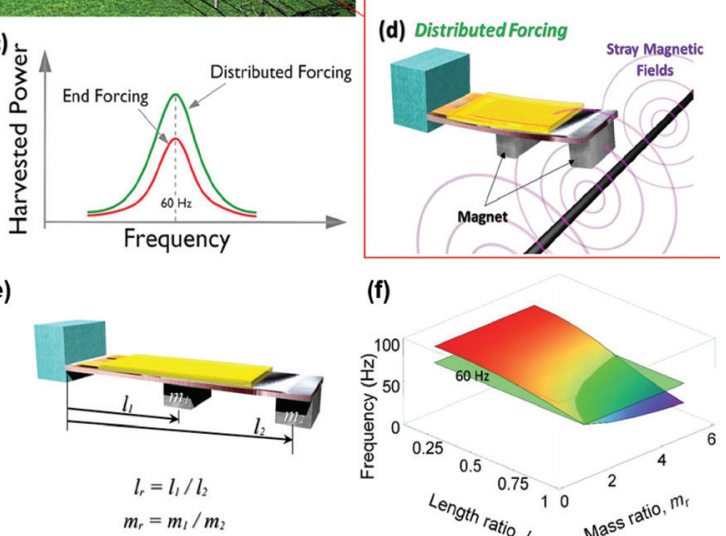

(g)
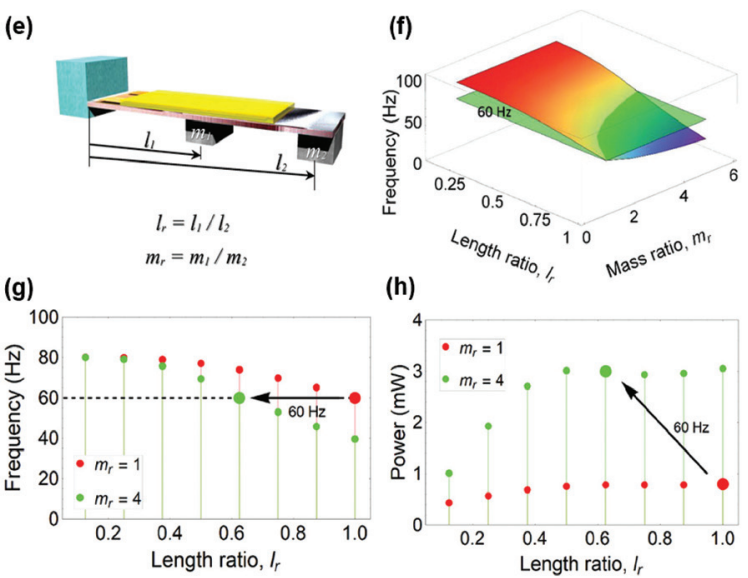

(h)

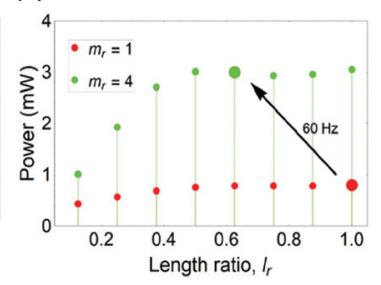

Fig. 10. (a) Conceptual illustration of a drone powered by MME generator near high voltage power lines, (b) configuration of MME generators with and without distributed forcing, (c) expected normalized power with and without distributed forcing on MME generator operated at $60 \mathrm{~Hz}$ frequency, (d) configuration of a distributed forcing MME generator, (e) perspective view of dual mass generator showing mass and length ratios, ( $f$ ) frequency variation with length and mass ratio, $(\mathrm{g})$ frequency change for two mass ratios as a function of length ratio, (h) output power from the MME generator with different mass and length ratios. Adapted from Sriramdas et al. Adv. Energy Mater. 2020;10:1903689 with permission of Wiley [12].

을 공급하는데 이용될 수 있다. 현재까지 연구된 자기전기 복합체 기반 에너지 발전소자의 구조는 그림 10(b) 와 같이 캔틸레버의 끝 부분에만 자석 질량체가 위치한 구조였는데, 본 연구에서는 캔틸레버 중심부위에 자석 질량체를 추가로 부착하여 그림 $10(\mathrm{~d})$ 와 같은 자석 질량 체 분산형 자기-전기 발전소자를 개발하였다. 일반적인 
전력선이 $60 \mathrm{~Hz}$ 의 교류 자기장을 방출하기 때문에 발전 소자의 공진주파수도 $60 \mathrm{~Hz}$ 로 고정해야 한다. 발전소자 의 에너지 출력을 향상하기 위해서는 캔틸레버 끝부분 에 부착되는 자석 질량체의 부피/중량을 향상하여 자기 력 및 중력을 높이는 것이 가장 쉬운 방법인데, 이럴 경 우 자기-전기 복합체의 공진주파수도 감소하는 문제점 이 있다. 반면 추가적인 자석 질량체를 캔틸레버 구조체 의 중간부분에 부착하면 캔틸레버의 끝부분에 자석질량 체를 부착한 것과 비교했을 때 공진 주파수는 $60 \mathrm{~Hz}$ 로 유지하면서 더 많은 자석 질량체의 부피/중량을 달성할 수 있다. 이러한 원리로 말미암아 분산형 자석 질량체 를 이용하는 경우, 자석 질량체를 캔틸레버 끝에만 부착 하는 경우와 비교했을 때 그림 10(c)에서처럼 높은 에너 지 출력을 기대할 수 있다. 연구팀은 자기-전기 복합체 에서 출력되는 에너지의 극대화를 위해 그림 $10(\mathrm{e})$ 처럼 캔틸레버 끝과 중간 부분에 부착되는 자석 질량체의 질 량비 및 거리비를 조절하며 공진 주파수가 어떻게 변화 하는지를 살펴보았는데, 그림 $10(\mathrm{f}),(\mathrm{g})$ 와 같이 자석 질 량체의 질량비 및 거리비에 따라 공진 주파수는 큰 차이 를 보여주었다. 전력선에서 발생하는 교류 주파수는 60 $\mathrm{Hz}$ 이므로 자기-전기 복합체의 공진 주파수가 $60 \mathrm{~Hz}$ 인 경우만 에너지 발전에 사용할 수 있는데, 자석 질량체의 질량비가 4 , 거리비가 0.6 일 경우와 자석 질량체의 무게 비 1 , 거리비가 1 인 경우에 자기-전기 복합체의 공진주 파수를 $60 \mathrm{~Hz}$ 로 맞출 수 있었다. 이때 거리비가 1인 경 우는 자석 질량체가 캔틸레버의 끝에 붙어 있는 경우이 고, 1 보다 작은 경우에는 질량체가 분산된 경우이다. 또 한 자석 질량체의 질량비 및 거리비에 따른 에너지 출력 값을 그림 $10(\mathrm{~h})$ 와 같이 측정해 보았다. 전력선에서 실 제로 사용할 수 있는 $60 \mathrm{~Hz}$ 의 공진주파수의 경우만 비 교해 보았을 때, 자석 질량체가 분산형으로 캔틸레버에 부착되었을 때는 끝 부분에 위치한 경우보다 약 3 배 정 도 높은 전력을 발생할 수 있음을 알 수 있다. 이러한 분 산형 질량체 구성은 일정한 주파수에서 매우 간단한 방 법으로 자기-전기 발전소자의 출력을 매우 크게 증가시 키는 접근법인 것을 확인하였다. (a)

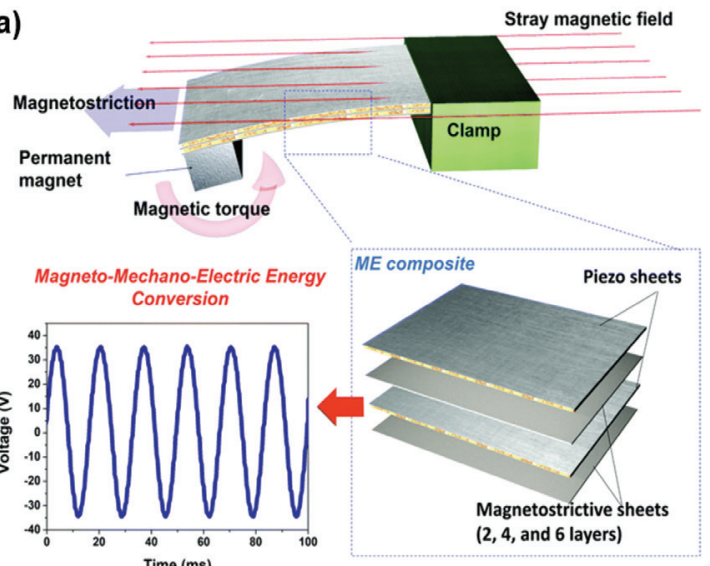

(b)

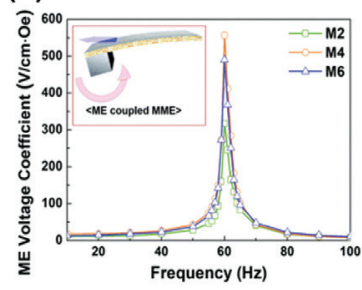

(c)

(d) ${ }_{12}$

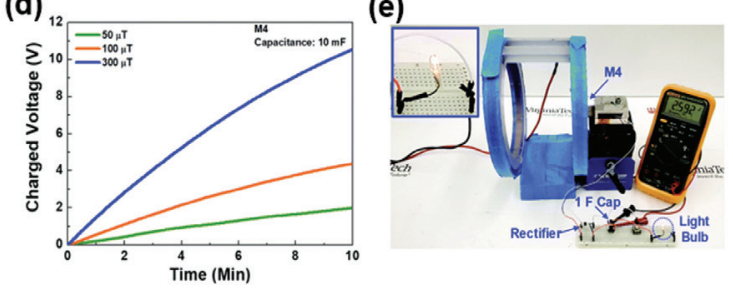

Fig. 11. (a) Schematic for working mechanism of MME generator and structural design, (b) frequencydependent magnetoelectric voltage coefficient of MME generators, (c) power output of MME generator with different magnetic fields, (d) charging curves for $10 \mathrm{mF}$ capacitor under various magnetic fields, (e) photograph image of powering light bulb by MME generator. Adapted from Sriramdas et al. Energy Environ. Sci. 2020;13:1462-1472 with permission of Royal Society of Chemistry [13].

\section{5 다중 압전층 도입을 통한 자기-전기 복합체 발전소자 개발}

지금까지 자기-전기 복합체 발전소자의 성능을 향 상하기 위해 다양한 시도가 있었는데 앞서 언급한 자왜 층의 개선 외에도, 2020 년 미국 펜실베니아 주립대학 교 연구팀은 2 개의 압전체을 도입하여 자기-전기 발전 소자의 성능을 향상하는 연구를 진행하였다. ${ }^{13)}$ 본 연구 
에서는 자왜재료로 Metglas, 압전재료로는 표준 PZT$5 \mathrm{~A}$ 를 이용하였다. 소자의 구조는 그림 $11(\mathrm{a})$ 와 같이 일 반적인 캔틸레버 형태를 가지고 있는데, 자왜층과 압전 층을 번갈아 가며 제작하는 2 개층의 압전구조를 가지고 있는 것이 특징이다. 자기-전기변환 과정에서 캔틸레버 가 상하로 진동을 하게 되는데, 2 개층의 압전층을 가지 고 있으면 기존 압전층이 하나 있는 구조보다 출력을 많 이 얻을 수 있다. 외부에서 교류 자기장이 가해지면, 기 존 캔틸레버 형태의 자기-전기 복합체와 마찬가지로 자 왜재료의 변형 및 자석 질량체에서의 자기력이 발생하 여 캔틸레버의 상하 진동을 발생시킨다. 출력의 극대화 를 위해서 Metglas 호일층의 개수를 2층, 4층, 6층으로 변화시키며 자기-전기 복합체에서 생성되는 에너지 출 력을 비교해 보았다. 먼저 자기-전기 변환계수를 측정 해 보았는데, Metglas를 2층, 4층, 6 층으로 형성하였을 때 그림 $11(\mathrm{~b})$ 처럼 약 $310 \mathrm{~V} / \mathrm{cm} \cdot \mathrm{Oe}, 480 \mathrm{~V} / \mathrm{cm} \cdot \mathrm{Oe}$, $550 \mathrm{~V} / \mathrm{cm}$ - Oe의 값을 나타내어 4층의 Metglas 구조 를 이용할 때 가장 높은 자기-전기 변환특성을 나타내 는 것을 확인하였다. 다음으로 그림 $11(\mathrm{c})$ 와 같이 4층 Metglas 구조의 발전소자를 이용해 전력을 측정해 보았 다. 외부에서 가해지는 교류 자기장이 $0.5 \mathrm{Oe}, 1 \mathrm{Oe}, 3$ $\mathrm{Oe}, 5 \mathrm{Oe}$ 일 때의 전력을 각각 측정해 보았는데, 자기장 이 높아질수록 출력되는 전력은 점점 증가하여 $3 \mathrm{Oe}$ 일 때는 $2.3 \mathrm{~mW}, 5 \mathrm{Oe}$ 일때는 $5.3 \mathrm{~mW}$ 를 달성하였다. 이 는 현존하는 자기-전기 복합체 기반 발전소자 중 최고 수준의 성능이라고 할 수 있는데, 다층의 압전체를 사용 하였기 때문에 달성이 가능한 수치이다. 다음으로 다중 압전층의 자기-전기 복합체 발전소자를 이용해 다양한 응용을 진행하였는데, $10 \mathrm{mF}$ 의 수퍼 커패시터를 그림 $11(\mathrm{~d})$ 와 같이 충전하였다. 자기-전기 복합체에 가해지 는 교류 자기장의 크기가 높을수록 큰 에너지 출력이 나 오기 때문에 커패시터 충전속도 역시 자기장이 클수록 빠른 것을 알 수 있었다. 다음 순서의 응용을 위해 비교 적 용량이 큰 $1 \mathrm{~F}$ 의 수퍼 커패시터를 충전시켰고, 크기 가 작은 백열 전구를 그림 $11(\mathrm{e})$ 와 같이 점등하는데 성공 하였다. 본 논문에서의 결과는 기존의 연구결과와 비교 했을 때 $3 \mathrm{Oe}$ 의 작은 크기의 교류 자기장에서 $1 \mathrm{~mW}$ 이
상의 에너지 출력을 낸 것이 특징이라고 할 수 있고, 층 상형 자기-전기 복합체는 사물인터넷 구동용 발전장치 로 널리 쓰일 수 있음을 보여주었다.

\section{5. 결론}

본 리뷰에서는 자왜소재와 압전소재의 결합을 이용 한 자기-전기 복합체의 간략한 역사, 동작원리, 응용분 야 및 최근 연구동향에 대해 살펴보았다. 자기-전기 복 합체는 자기장을 전기 에너지로 변환할 수 있기 때문에 에너지 하베스팅 및 미세 자기장 감지 분야에 널리 이용 할 수 있다. 특히 층상형 자기-전기 복합체는 우수한 특 성으로 말미암아 에너지 하베스팅 및 미세 자기장 감지 분야에서 최고의 특성을 보여주고 있다. 자기-전기 층 상 복합체의 성능 향상을 위해 현재까지 자왜 및 압전층 에 대한 다양한 방법으로 개선이 이루어졌고, 매우 높은 수준의 자기-전기 변환계수를 달성하여 응용범위를 더 욱더 넓혀 주었다. 에너지 하베스팅 분야에서는 수 $\mathrm{mW}$ 의 에너지 출력을 달성하여 다양한 사물인터넷 센서의 전원으로 활용하고 있으며, 자기장 감지 시스템 구성을 통해 자성체의 위치파악 및 이미징이 가능하다. 향후 자 기-전기 층상형 복합체를 이용해 에너지 하베스팅 특성 을 $100 \mathrm{~mW}$ 이상으로 높이고, 초미세 자기장 감지 시스 템 제작을 위한 다양한 시도가 성공한다면 사물인터넷 및 질병진단 분야에서 기존의 시스템을 대체하여 큰 기 술적, 경제적 파급효과를 가져올 수 있을 것으로 예상된 다. 향후 다양한 분야에서의 실용화를 위한 새로운 연구 시도 및 기반 환경의 탐색이 필요하고, 장기구동 신뢰성 분석 등의 추가적인 연구가 지속적으로 이루어져야 할 것이다.

\section{REFERENCES}

1.P. Haribabu, "Status and perspectives of multiferroic magnetoelectric composite materials and applications," Actuators, 5 [1] (2016).

2. J. Ryu, "자기-전기 복합체를 이용한 에너지 하베스터 
기술," Ceramist, 18[4] 38-47 (2015).

3. 이경우, 소형종, 임실묵, 김원호, 김대연, "1-3 형 압 전복합체를 이용한 광대역 수중 음향 트랜스듀서 개 발,"한국소음진동공학회논문집, 18[4], 424-431 (2008).

4. J. Ryu, J.-E. Kang, Y. Zhou, S.-Y. Choi, and D.-Y. Jeong, "Ubiquitous Magneto-Mechano-Electric Generator," Energy Environ. Sci., 8 2402-8 (2015).

5. J. Ryu, S. Priya, K. Uchino, and H. E. Kim, "Magnetoelectric effect in composites of magnetostrictive and piezoelectric materials," Journal of electroceramics, 8[2], 107-119 (2002).

6. V. Annapureddy, S. M. Na, and J. Ryu, "Exceeding milli-watt powering magneto-mechano-electric generator for standalone-powered electronics," Energy Environ. Sci., 11[4], 818-829 (2018).

7. G.-T. Hwang, H. Palneedi, and J. Ryu, "Enhancement of magnetoelectric conversion achieved by optimization of interfacial adhesion layer in laminate composites," ACS applied materials \& interfaces, 10[38], 32323-32330 (2018).

8. M. PourhosseiniAsl, X. Gao, and S. Dong, "Versatile power and energy conversion of magnetoelectric
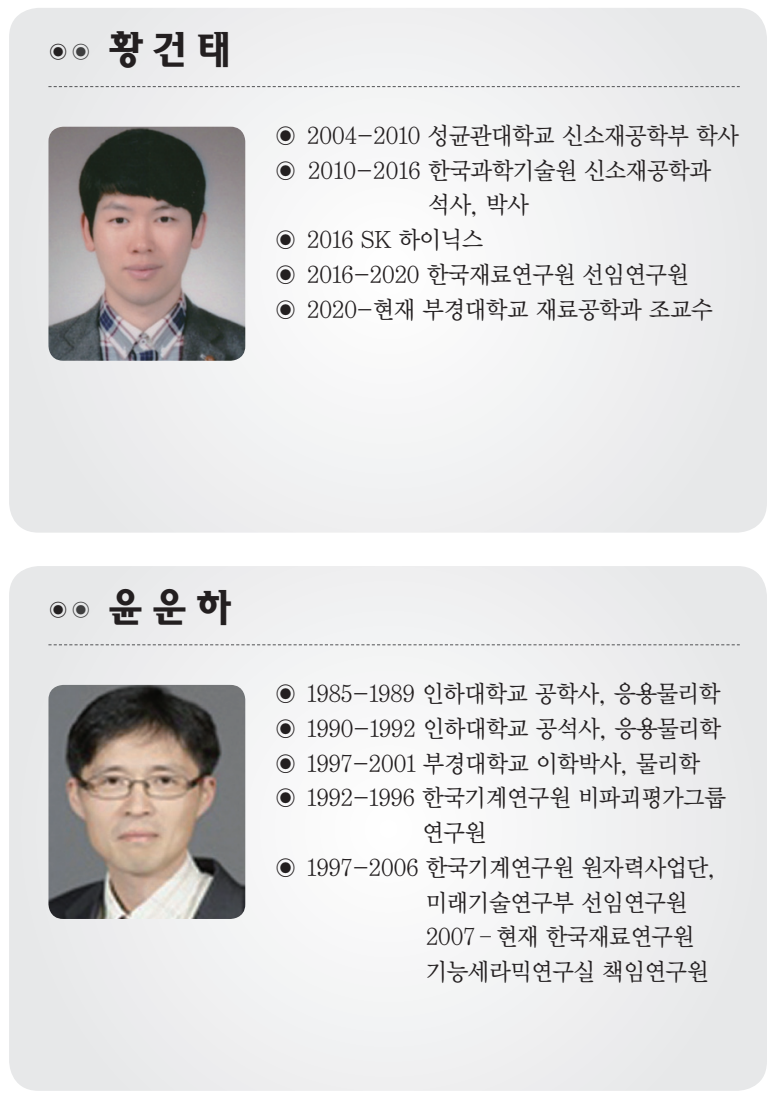

composite materials with high efficiency via electromechanical resonance," Nano Energy, 70, 104506 (2020).

9. G.-T. Hwang, H. Song, J. Jang, J. Ryu, W.-H. Yoon, "Sensing of ultra-low magnetic field by magnetoelectric (ME) composites," Ceramist., 23[1], 38-53 (2020).

10. Z. Chu, W. Shi, H. Shi, and S. Dong, “A 1D Magnetoelectric Sensor Array for Magnetic Sketching," Adv. Mater. Technol., 4, 1800484 (2019).

11. M. G. Kang, R. Sriramdas, H. Lee, and S. Priya, "High Power Magnetic Field Energy Harvesting through Amplified Magneto-Mechanical Vibration," Adv. Energy Mater., 8, 1703313 (2018)

12. R. Sriramdas, M.-G. Kang, M. Meng, J. Ryu, and S. Priya, "Large Power Amplification in MagnetoMechano-Electric Harvesters through distributed Forcing," Adv. Energy Mater, 10, 1903689 (2020).

13. H. Lee, R. Sriramdas, P. Kumar, and S. Priya, "Maximizing power generation from ambient stray magnetic fields around smart infrastructures enabling self-powered wireless devices," Energy Environ. Sci., 13, 1462 (2020).

\section{○○류 정 호}

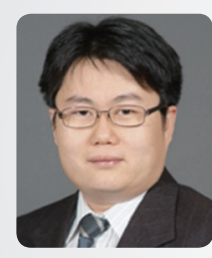

( 1992-1998 영남대학교 무기재료공학과 학사, 석사

( 1998-2001 서울대학교 재료공학부 박사

- 2000-2003 Pennsylvania State University 방문연구원, 박사 후 연구원

( 2003-2006 삼성전기 OS 사업부 책임연구원

- 2006-2018 한국재료연구원 책임연구원

( 2018-현재 영남대학교 신소재공학부 교수 
특 집 미 황건태, 류정호, 윤운하 